\title{
ANALISIS DAERAH RAWAN KECELAKAAN LALU LINTAS JALAN RAYA NGERONG CEMOROSEWU
}

\author{
${ }^{1}$ Eyvritto Eltama Styana Putra, ${ }^{2}$ Silvia Yulita Ratih, ${ }^{3}$ Luky Primantari \\ ${ }^{123}$ Program Studi Teknik Sipil, Fakultas Teknik Sipil dan Perencanaan, \\ Universitas Surakarta \\ Email: ${ }^{1}$ eyvritto26@gmail.com, ${ }^{2}$ vierahayu1125@gmail.com, \\ ${ }^{3}$ lukyprima@yahoo.com/HP. 0812282104032
}

\begin{abstract}
ABSTRAK
Penambahan jumlah penduduk serta peningkatan jumlah kendaraan akan menimbulkan konsekuensi baru dalam berlalu lintas seperti kebutuhan fasilitas jalan yang lebih baik, pelanggaran lalu lintas yang meningkat, serta resiko terjadinya kecelakaan lalu lintas juga semakin tinggi. Tujuan dari penelitian ini adalah untuk menganalisis daerah rawan kecelakaan jalan raya Ngerong Cemorosewu sehingga dapat diambil tindakan yang sesuai untuk mengurangi terjadinya kecelakaan pada ruas jalan tersebut. Metode yang digunakan untuk menentukan lokasi rawan kecelakaan lalu lintas adalah Metode EAN (Equivalent Accident Number). Jumlah kecelakaan tertinggi terjadi pada tahun 2020 dengan total 75 kejadian. Jumlah korban kecelakaan tertinggi terjadi pada tahun 2018 dengan total 92 korban dan terendah pada tahun 2020 dengan jumlah 64 korban. Bobot tingkat kecelakaan berdasarkan angka EAN adalah 852 pada 13 segmen pengamatan. Nilai BKA (Batas Kontrol Atas) adalah 89,3. Berdasarkan nilai EAN terlihat beberapa segmen berada diatas BKA dan UCL (Upper Control Limit) yaitu segmen 2 (KM. 13+000-KM. 14+000), segmen 8 (KM. 19+000-KM. 20+000), segmen 9 (KM. 20+000-KM. 21+000) dan segmen 10 (KM. 21+000-KM. $22+000)$, artinya bahwa di segmen tersebut masuk daerah rawan kecelakaan. Beberapa hal yang dapat dilakukan untuk mengurangi kecelakaan terutama akibat pengemudi adalah harus selalu waspada, jangan lengah, apabila merasa lelah atau mengantuk segera beristirahat serta tidak lupa mengecek kondisi kendaraan yang akan digunakan.
\end{abstract}

Kata Kunci: Daerah Rawan Kecelakaan, BKA, EAN, UCL

\section{ABSTRACT}

The increase in population and the enhancement in the number of vehicles will lead to new consequences in traffic, such as the need for better road facilities, the rise of traffic violations, and the risk of traffic accidents. The purpose of this study is to analyze the accident-prone areas of the Ngerong Cemorosewu highway so that appropriate action can be taken to reduce the occurrence of accidents on these roads. The method used to determine the location prone to traffic accidents is the EAN (Equivalent Accident Number) method. The highest number of accidents occurred in 2020 with a total of 75 incidents. The highest number of accident victims occurred in 2018 with a total of 92 victims and the lowest was in 2020 with 64 victims. The weight of the accident rate based on the EAN number is a852 in the 13 observation segments. The BKA (Batas Kontrol Atas) value is 89.3. Based on the EAN value, it can be seen that several segments are above BKA and UCL 
(Upper Control Limit), those are segment 2 (KM. 13+000-KM. 14+000), segment 8 (KM. 19+000-KM. 20+000), segment 9 (KM. $20+000-$ KM. 21+000) and segment 10 (KM. 21+000-KM. 22+000). It means that those segments are accidentprone areas. Some things that can be done to reduce accidents, especially for the drivers, are to always be alert, don't be careless, if you feel tired or sleepy, please take a rest immediately and don't forget to check the condition of the vehicle to be used.

Keywords: Accident Prone Areas, BKA, EAN, UCL

\section{PENDAHULUAN}

Jalan merupakan akses yang menghubungkan kawasan satu dengan kawasan lainya dan berguna untuk memberikan kemudahan kepada masyarakat bepergian ke tempat lain. Penambahan jumlah penduduk serta peningkatan jumlah kendaraan akan menimbulkan konsekuensi yang baru dalam berlalu lintas seperti kebutuhan fasilitas jalan yang lebih baik, pelanggaran lalu lintas yang meningkat, serta resiko terjadinya kecelakaan lalu lintas juga semakin tinggi.

Ruas jalan raya Ngerong Cemorosewu menghubungkan antara Kabupaten Magetan dengan Kabupaten Karanganyar. Ruas jalan ramai dengan kendaraan karena sebagai sarana penghubung daerah wisata di Tawangmangu dan sekitarnya. Sepanjang ruas jalan Ngerong-Cemorosewu terdapat beberapa daerah rawan terjadinya kecelakaan lalu lintas karena mempunyai kondisi geometrik jalan berupa turunan maupun tanjakan serta tikungan. Selain itu daerah tersebut merupakan daerah rawan bencana tanah longsor. Kondisi jalan yang berada di ketinggian juga mengakibatkan sering tertutup kabut sehingga mengganggu jarak pandang para pemakai jalan. Menurut data Satlantas Polres Magetan menunjukkan adanya fluktuasi peristiwa kecelakaan lalu lintas dari tahun 2018, 2019 dan 2020.

Kejadian kecelakaan yang terjadi di ruas jalan akan mengakibatkan kerugian bagi pemakai jalan. Tujuan dari penelitian ini adalah untuk menganalisis daerah rawan kecelakaan sehingga dapat diambil tindakan yang sesuai untuk mengurangi terjadinya kecelakaan pada ruas jalan tersebut.

\section{TINJAUAN PUSTAKA}

Transportasi bertujuan untuk mewujudkan lalu lintas dan angkutan jalan dengan selamat, aman, cepat, lancar, tertib dan teratur, nyaman dan efisien, mampu memadukan moda transportasi lainnya. Semakin banyaknya kegiatan transportasi akan memberikan akibat permasalahan seperti kemacetan atau kecelakaan lalu lintas). Pelanggaran lalu lintas yang cukup tinggi serta kepemilikan kendaraan pribadi yang semakin hari semakin meningkat, hal ini secara tidak langsung akan memicu terjadinya kecelakaan lalu lintas (UU No. 22 tahun 2009). Keselamatan merupakan hal yang serius dan wajib diperhitungkan oleh para pengguna jasa dalam bidang transportasi (Agus Alisa Putra, Arfi Desrimon, 2019).

Peningkatan jumlah penduduk akan mempengaruhi kebutuhan transportasi yang akan terus meningkat, secara tidak langsung juga akan menimbulkan beberapa masalah yang harus diperhatikan, seperti masalah kecelakaan lalu lintas (Intan Kristalia Feryanti, 2019). Kecelakaan lalu lintas merupakan aspek negatif dari peningkatan mobilitas transportasi yang meningkat pesat jika tidak di dukung prasarana yang mengedepankan fungsi keselamatan. Frekuensi kecelakaan lalu lintas yang akhir-akhir ini cenderung meningkat, selain disebabkan oleh faktor 
manusia (human error) juga faktor jalan dan lingkungan ikut berperan sebagai faktor penyebab kecelakaan (Imam Syamsudin, 2019).

Kecelakaan lalu lintas yang terjadi dapat disebabkan karena ketidakseimbangan antara pengemudi, kendaraan dan prasarana lalu lintas yang merupakan unsur kegiatan transportasi (Bela Titisari, 2019). Faktor manusia merupakan faktor yang paling dominan dalam kecelakaan. Hampir semua kejadian kecelakaan didahului dengan pelanggaran rambu-rambu lalu lintas. Pelanggaran dapat terjadi karena sengaja melanggar, ketidaktahuan terhadap arti aturan yang berlaku ataupun tidak melihat ketentuan yang diberlakukan. Kecelakaan lalu lintas umumnya terjadi karena berbagai faktor penyebab seperti pelanggaran atau tindakan tidak hati-hati para pengguna (pengemudi dan pejalan kaki), kondisi jalan, kondisi kendaraan, cuaca dan pandangan yang terhalang (Muhammad Fakhruriza Pradana, Dwi Esti Intari, Danur Pratidina, 2019). Kepadatan lalu lintas termasuk salah satu faktor penyebab terjadi kecelakaan dari beberapa faktor lainnya (Dwi Esti Intari, Hendrian Budi Bagus Kuncoro, Riana Pangestika, 2019).

Kecelakaan lalu lintas merupakan indikator utama tingkat keselamatan jalan raya. Di negara maju masalah keselamatan jalan merupakan masalah yang sangat diperhatikan untuk mereduksi kuantitas kecelakaan yang terjadi. Jumlah korban yang cukup besar akan memberikan dampak ekonomi (kerugian material) dan sosial yang tidak sedikit (Asep Fahza, Hera Widyastuti, 2019). Kejadian kecelakaan yang terjadi di ruas jalan mengakibatkan banyaknya kerugian baik kerugian materil maupun non materiil (Nugroho Utomo, 2012). Salah satu upaya untuk meningkatkan keselamatan transportasi yaitu dengan penentuan dan penanganan lokasi rawan kecelakaan lalu lintas (Gito Sugiyanto, Ari Fadli, 2016)

\section{Daerah Rawan Kecelakaan}

Daerah rawan kecelakaan merupakan daerah yang mempunyai angka kecelakaan tinggi, resiko serta potensi kecelakaan yang tinggi pada ruas jalan. Daerah rawan kecelakaan lalu lintas dapat dikelompokkan menjadi tiga yaitu:

1. Lokasi rawan kecelakaan (hazardous sites)

Lokasi atau site merupakan daerah-daerah tertentu yang meliputi pertemuan jalan, acces point serta ruas jalan yang pendek. Lokasi rawan kecelakaan dikelompokkan menjadi dua yaitu:

a. Blacksite/section merupakan ruas daerah rawan kecelakaan lalu lintas

b. Blackspot merupakan titik pada ruas daerah rawan kecelakaan lalu lintas.

2. Rute rawan kecelakaan (hazardous routes)

Panjang pada rute suatu kecelakaan biasanya ditetapkan lebih dari 1 kilometer.

3. Wilayah rawan kecelakaan (hazardous area)

Luas wilayah rawan kecelakaan (hazardous area) biasanya ditetapkan berkisaran antara $5 \mathrm{~km}^{2}$.

Metode yang digunakan untuk menentukan daerah rawan kecelakaan adalah:

1. Metode Equivalent Accident Number (EAN).

Metode ini digunakan untuk menghitung angka kecelakaan setiap titik. Rumus EAN sebagai berikut:

$\mathrm{EAN}=(12 \times M D)+(3 \times L B)+(3 \times L R)$

dengan:

EAN $=$ Equivalent Accident Number

$\mathrm{MD}=$ Meninggal Dunia 


$$
\begin{aligned}
& \text { LB }=\text { Luka Berat } \\
& \text { LR }=\text { Luka Ringan }
\end{aligned}
$$

Penentuan lokasi rawan kecelakaan dilakukan berdasarkan angka kecelakaan tiap kilometer jalan yang memiliki nilai bobot (EAN) melebihi nilai batas tertentu. Batas ini dapat dihitung antara lain dengan menggunakan metode Batas Kontrol Atas (BKA) dan Upper Control Limit (UCL).

2. Metode Batas Kontrol Atas (BKA).

Batas Kontrol Atas (BKA) adalah metode untuk mengidentifikasi batasan tingkat kecelakaan dengan nilai rata-rata seluruh angka kecelakaan yang terjadi. Rumus BKA sebagai berikut:

$\mathrm{BKA}=\mathrm{C}+3 \sqrt{\mathrm{C}}$

dengan:

$$
\mathrm{C}=\text { Rata-rata angka kecelakaan EAN }
$$

3. Metode Upper Control Limit (UCL).

Metode yang digunakan untuk menentukan daerah rawan kecelakaan dengan tingkat per segmen/ blacksite sehingga diperoleh titik kecelakaan/blackspot. Nilai Upper Control Limit (UCL) ditentukan dengan menggunakan persamaan sebagai berikut:

$\mathrm{UCL}=\boldsymbol{\lambda}+\Psi \times \sqrt{ }([\boldsymbol{\lambda} / \boldsymbol{m})+(0.829) / \mathrm{m}+(1 / 2 \times m)])$

dengan:

$\lambda=$ Rata-rata angka kecelakaan EAN

$\Psi \quad=$ Faktor probabilitas 2.576

$\mathrm{M}=$ Angka kecelakaan ruas yang ditijau (EAN)

Jika suatu segmen ruas jalan memiliki angka kecelakaan berada di atas garis $U C L$ maka segmen ruas jalan tersebut diidentifikasi sebagai lokasi rawan kecelakaan lalu lintas.

\section{METODE PENELITIAN}

\section{Lokasi Penelitian}

Lokasi penelitian dilakukan pada Ruas Jalan Ngerong-Cemorosewu KM. 12+000 KM. 25+000 di Kabupaten Magetan seperti pada gambar 1.

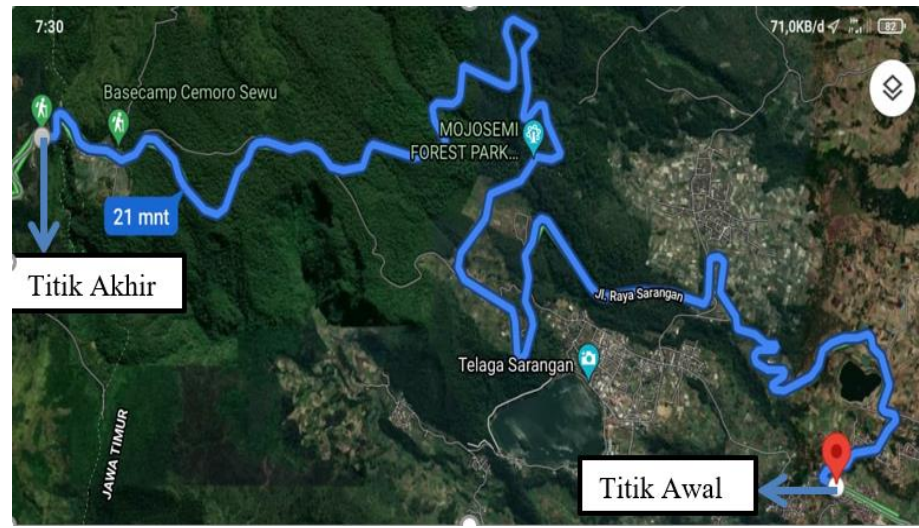

Gambar 1. Lokasi Penelitian

Metode penelitian menggunakan penelitian kuantitatif. Penelitian kuantitatif merupakan suatu penelitian ilmiah yang disusun secara sistematis terhadap bagian- 
bagian serta mencoba menemukan kausalitas yang baik. Dalam model penelitian kuantitatif hasil analisis akan berupa angka.

Langkah - langkah penelitian yang dilakukan sebagai berikut:

1. Melakukan pengamatan di lokasi penelitian untuk mendapatkan kondisi ruas jalan antara lain kelengkapan sarana dan prasarana seperti rambu-rambu lalu lintas, median jalan, situasi jalan serta kondisi jalan.

2. Pengambilan data kecelakaan lalu lintas yang didapat dari Polres Magetan tahun 2018-2020 dan rekapitulasi jumlah kecelakaan lalu lintas yang terjadi pada ruas jalan tersebut.

3. Pengolahan data dan melakukan analisis untuk menentukan daerah rawan kecelakan pada ruas jalan tersebut.

4. Menemukan langkah yang tepat untuk mengurangi jumlah kecelakaan lalu lintas yang terjadi.

\section{HASIL DAN PEMBAHASAN}

Ruas Jalan Ngerong Cemorosewu KM. 12+000 - KM. 25+000 dibagi menjadi 13 segmen dengan setiap segmen sepanjang 1 kilometer. Kondisi jalan berupa belokan, tanjakan dan turunan terlihat seperti pada gambar 2 .
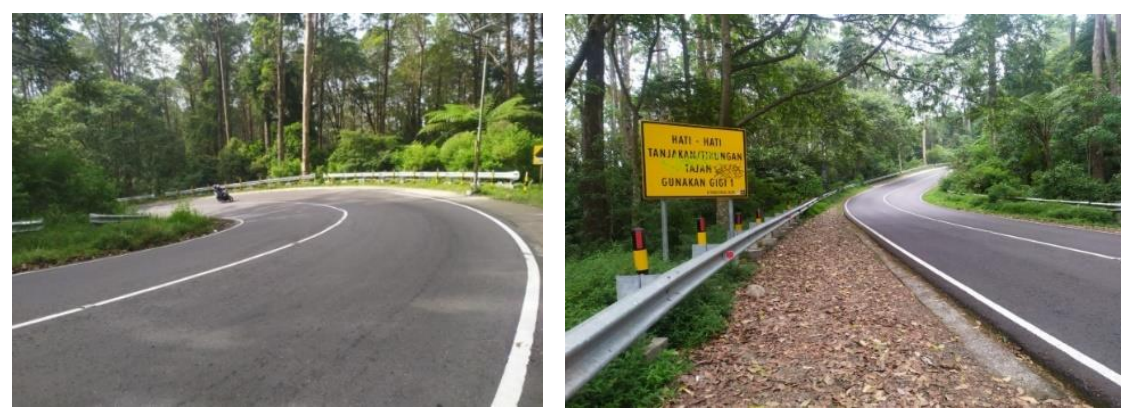

Gambar 2. Kondisi Existing Jalan

\section{Jumlah Kecelakaan Lalu Lintas Tahun 2018, 2019 dan 2020}

Jumlah kecelakaan lalu lintas pada tahun 2018, 2019 seperti pada tabel 1.

Tabel 1. Jumlah Kecelakaan Lalu Lintas Tahun 2018, 2019 dan 2020

\begin{tabular}{|c|c|c|c|c|c|}
\hline \multirow{2}{*}{ Segmen } & \multirow{2}{*}{ Ruas Jalan } & \multicolumn{3}{|c|}{ Tahun } & $\begin{array}{c}\text { Jumlah } \\
\text { Kejadian }\end{array}$ \\
\cline { 3 - 6 } & & $\mathbf{2 0 1 8}$ & $\mathbf{2 0 1 9}$ & $\mathbf{2 0 2 0}$ & \\
\hline 1 & KM. 12+000-KM. 13+000 & 7 & 5 & 5 & 17 \\
\hline 2 & KM. 13+000-KM. 14+000 & 8 & 5 & 11 & 24 \\
\hline 3 & KM. 14+000-KM. 15+000 & 4 & 5 & 1 & 10 \\
\hline 4 & KM. 15+000-KM 16+000 & 4 & 6 & 8 & 18 \\
\hline 5 & KM. 16+000-KM. 17+000 & 3 & 0 & 5 & 8 \\
\hline 6 & KM. 17+000-KM. 18+000 & 2 & 8 & 4 & 14 \\
\hline 7 & KM. 18+000-KM. 19+000 & 8 & 4 & 6 & 18 \\
\hline 8 & KM. 19+000-KM. 20+000 & 5 & 8 & 10 & 23 \\
\hline 9 & KM. 20+000-KM. 21+000 & 7 & 10 & 8 & 25 \\
\hline 10 & KM. 21+000-KM. 22+000 & 10 & 8 & 5 & 23 \\
\hline 11 & KM. 22+000-KM. 23+000 & 4 & 5 & 6 & 15 \\
\hline 12 & KM. 23+000-KM. 24+000 & 0 & 0 & 6 & 6 \\
\hline 13 & KM. 24+000-KM. 25+000 & 0 & 0 & 0 & 0 \\
\hline & Jumlah & $\mathbf{6 2}$ & $\mathbf{6 4}$ & $\mathbf{7 5}$ & $\mathbf{2 0 1}$ \\
\hline
\end{tabular}




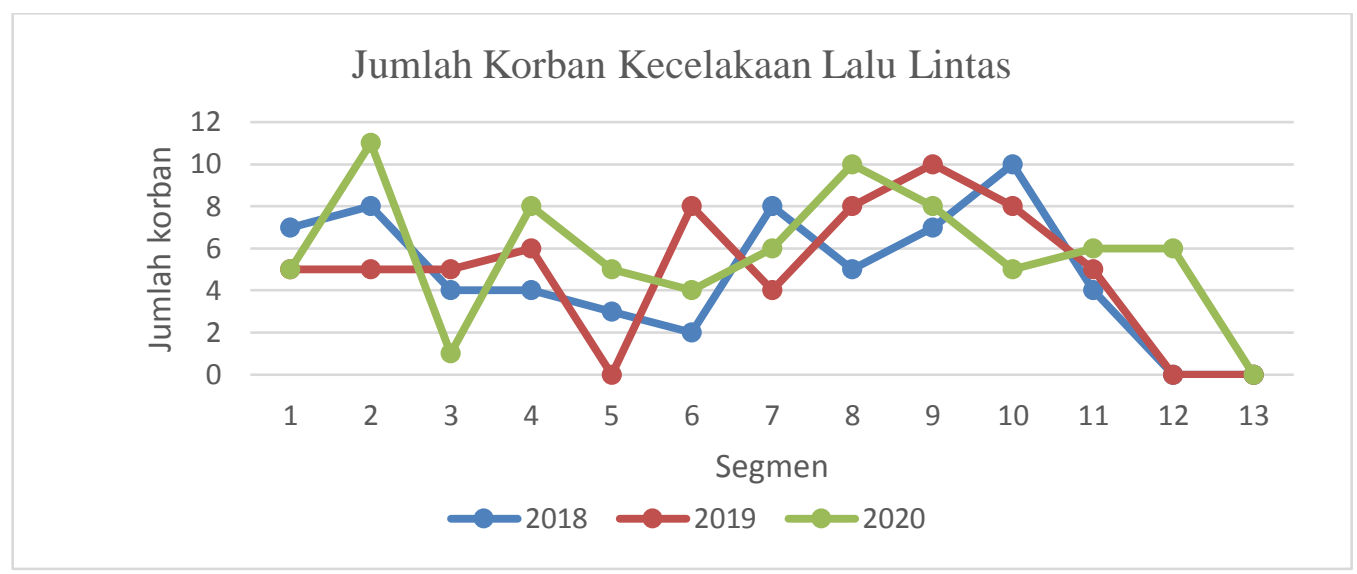

Gambar 3. Grafik jumlah Korban Kecelakaan Lalu Lintas

Dari tabel 1 dan gambar 3 terlihat jumlah kecelakaan yang paling tinggi pada tahun 2020 sebanyak 95. Sedangkan jumlah kejadian kecelakaan tertinggi terjadi pada segmen 9 (KM. 20+000-KM. 21+000) dengan jumlah total 25 kejadian kecelakaan.

\section{Jenis Kecelakaan dan Jumlah Korban Kecelakaan}

Tabel 2. Jenis Kecelakaan dan Jumlah Korban Kecelakaan

\begin{tabular}{|c|c|c|c|c|c|}
\hline \multirow{2}{*}{ No } & Tahun & $\begin{array}{c}\text { Meninggal } \\
\text { Dunia }\end{array}$ & $\begin{array}{c}\text { Luka } \\
\text { Berat }\end{array}$ & $\begin{array}{c}\text { Luka } \\
\text { Ringan }\end{array}$ & $\begin{array}{c}\text { Jumlah } \\
\text { (Korban) }\end{array}$ \\
\cline { 3 - 5 } & 2018 & 12 & 10 & 70 & 92 \\
\hline 2 & 2019 & 8 & 7 & 48 & 63 \\
\hline 3 & 2020 & 5 & 6 & 43 & 54 \\
\hline \multicolumn{2}{r}{ Jumlah } & $\mathbf{2 5}$ & $\mathbf{2 3}$ & $\mathbf{1 6 1}$ & $\mathbf{2 0 9}$ \\
\hline
\end{tabular}

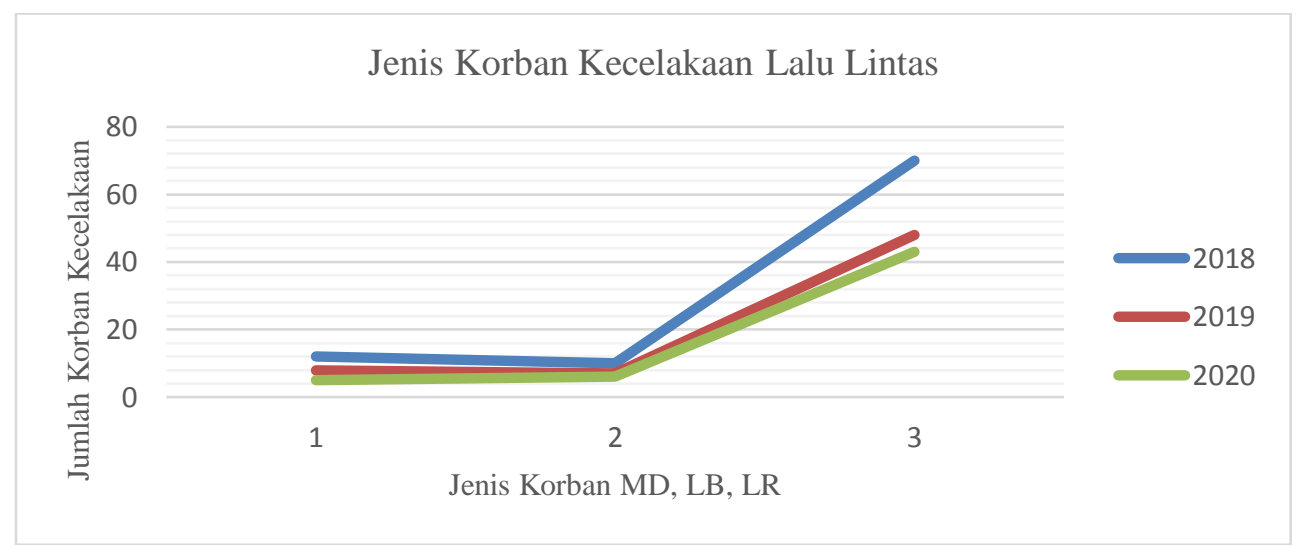

Gambar 4. Jenis Korban Kecelakaan Lalu Lintas

Dari tabel 2 dan gambar 4 terlihat jenis korban kecelakaan yang paling tinggi pada tahun 2108 dengan total 92 korban baik yang meninggal dunia, luka berat maupun luka ringan. Jumlah korban kecelakaan terjadi penurunan setiap tahun dan terendah 2020 dengan jumlah 54 korban. 


\section{Faktor Penyebab Kecelakaan}

Tabel 3. Faktor Penyebab Kecelakaan

\begin{tabular}{|c|c|c|c|c|c|}
\hline \multirow[t]{2}{*}{ No } & \multirow{2}{*}{$\begin{array}{c}\text { Faktor Penyebab } \\
\text { Kecelakaan }\end{array}$} & \multicolumn{3}{|c|}{ Jumlah Kecelakaan } & \multirow{2}{*}{ Total } \\
\hline & & 2018 & 2019 & 2020 & \\
\hline A & Pengemudi & & & & \\
\hline 1 & Lengah/Kurang Hati-Hati & 35 & 31 & 38 & 104 \\
\hline 2 & Mengantuk & 5 & 6 & 3 & 14 \\
\hline 3 & Mabuk & 0 & 0 & 2 & 2 \\
\hline \multirow[t]{2}{*}{4} & Lain-Lain & 0 & 0 & 0 & 0 \\
\hline & Sub Total & 40 & 37 & 43 & 120 \\
\hline B & Kendaraan & & & & \\
\hline 1 & Selip & 1 & 3 & 0 & 4 \\
\hline 2 & Rem Blong & 20 & 17 & 24 & 61 \\
\hline 3 & Kerusakan Mekanis & 0 & 0 & 0 & 0 \\
\hline 4 & Kerusakan Mesin & 0 & 0 & 0 & 0 \\
\hline 5 & Ban Pecah & 1 & 1 & 2 & 4 \\
\hline \multirow[t]{2}{*}{6} & Lain-Lain & 0 & 0 & 0 & 0 \\
\hline & Sub Total & 22 & 21 & 26 & 69 \\
\hline $\mathrm{C}$ & Jalan dan Lingkungan & & & & \\
\hline 1 & Kerusakan Jalan & 0 & 0 & 0 & 0 \\
\hline 2 & Perlengkapan Jalan & 0 & 6 & 6 & 12 \\
\hline 3 & Asap Kendaraan & 0 & 0 & 0 & 0 \\
\hline 4 & Material di Jalan & 0 & 0 & 0 & 0 \\
\hline \multirow[t]{2}{*}{5} & Lain-Lain & 0 & 0 & 0 & 0 \\
\hline & Sub Total & 0 & 6 & 6 & 12 \\
\hline \multicolumn{2}{|r|}{ Total } & 62 & 64 & 75 & 201 \\
\hline
\end{tabular}

Dari tabel 3 terlihat bahwa faktor terbanyak penyebab kecelakaan adalah dari pengemudi terutama karena lengah atau kurang hati-hati. Yang dapat dilakukan untuk mengurangi kecelakaan terutama akibat pengemudi adalah harus selalu waspada, jangan lengah, apabila merasa lelah atau mengantuk segera beristirahat serta tidak lupa mengecek kondisi kendaraan yang akan digunakan terutama remnya.

Perhitungan Angka Kecelakaan Lalu Lintas

Bobot tingkat kecelakaan berdasarkan angka EAN seperti pada tabel 4.

Tabel 4. Bobot Tingkat Kecelakaan Berdasarkan Angka EAN.

\begin{tabular}{|l|l|l|l|l|l|l|l|}
\hline \multirow{2}{*}{ Ruas Jalan } & \multicolumn{3}{|c|}{$\begin{array}{c}\text { Jumlah } \\
\text { Kecelakaan }\end{array}$} & \multicolumn{3}{c|}{ Perhitungan EAN } & EAN \\
\cline { 2 - 9 } & MD & LB & LR & MD*12 & LB*3 & LR*3 & \\
\hline KM. 12+000-KM. 13+000 & 2 & 2 & 15 & 24 & 6 & 45 & 75 \\
\hline KM. 13+000-KM. 14+000 & 3 & 2 & 17 & 36 & 6 & 51 & 93 \\
\hline KM. 14+000-KM. 15+000 & 0 & 1 & 13 & 0 & 3 & 39 & 42 \\
\hline KM. 15+000-KM 16+000 & 1 & 2 & 10 & 12 & 6 & 30 & 48 \\
\hline KM. 16+000-KM. 17+000 & 1 & 0 & 12 & 12 & 0 & 36 & 48 \\
\hline KM. 17+000-KM. 18+000 & 1 & 4 & 10 & 12 & 12 & 30 & 54 \\
\hline KM. 18+000-KM. 19+000 & 3 & 0 & 13 & 36 & 0 & 39 & 75 \\
\hline KM. 19+000-KM. 20+000 & 4 & 2 & 18 & 48 & 6 & 54 & 108 \\
\hline KM. 20+000-KM. 21+000 & 3 & 3 & 22 & 36 & 9 & 66 & 111 \\
\hline
\end{tabular}


JURNAL KACAPURI

JURNAL KEILMUAN TEKNIK SIPIL

Volume 4 Nomor 2 Edisi Desember 2021

\begin{tabular}{|c|l|l|l|l|l|l|l|}
\hline KM. 21+000-KM. 22+000 & 4 & 2 & 17 & 48 & 6 & 51 & 105 \\
\hline KM. 22+000-KM. 23+000 & 3 & 5 & 8 & 36 & 15 & 24 & 75 \\
\hline KM. 23+000-KM. 24+000 & 0 & 0 & 6 & 0 & 0 & 18 & 18 \\
\hline KM. 24+000-KM. 25+000 & 0 & 0 & 0 & 0 & 0 & 0 & 0 \\
\hline Jumlah & 25 & 23 & 161 & 300 & 69 & 483 & 852 \\
\hline
\end{tabular}

Tabel 5. Nilai BKA (Batas Kontrol Atas) dan UCL (Upper Control Limit)

\begin{tabular}{|c|c|c|c|c|c|}
\hline \multirow{2}{*}{ Segmen } & Ruas Jalan & EAN & BKA & UCL & Kategori \\
\hline 1 & KM. 12+000-KM. 13+000 & 75 & 89,35 & 81,10 & Bukan Blacksite \\
\hline 2 & KM. 13+000-KM. 14+000 & 93 & 89,35 & 82,85 & Blacksite \\
\hline 3 & KM. 14+000-KM. 15+000 & 42 & 89,35 & 77,35 & Bukan Blacksite \\
\hline 4 & KM. 15+000-KM 16+000 & 48 & 89,35 & 78,12 & Bukan Blacksite \\
\hline 5 & KM. 16+000-KM. 17+000 & 48 & 89,35 & 78,12 & Bukan Blacksite \\
\hline 6 & KM. 17+000-KM. 18+000 & 54 & 89,35 & 78,83 & Bukan Blacksite \\
\hline 7 & KM. 18+000-KM. 19+000 & 75 & 89,35 & 81,10 & Bukan Blacksite \\
\hline 8 & KM. 19+000-KM. 20+000 & 108 & 89,35 & 84,15 & Blacksite \\
\hline 9 & KM. 20+000-KM. 21+000 & 111 & 89,35 & 84,46 & Blacksite \\
\hline 10 & KM. 21+000-KM. 22+000 & 105 & 89,35 & 84 & Blacksite \\
\hline 11 & KM. 22+000-KM. 23+000 & 75 & 89,35 & 81,10 & Bukan Blacksite \\
\hline 12 & KM. 23+000-KM. 24+000 & 18 & 89,35 & 74,36 & Bukan Blacksite \\
\hline 13 & KM. 24+000-KM. 25+000 & 0 & 89,35 & 0 & Bukan Blacksite \\
\hline \multicolumn{7}{|l}{ Jumlah } & $\mathbf{8 5 2}$ & & & \\
\hline
\end{tabular}

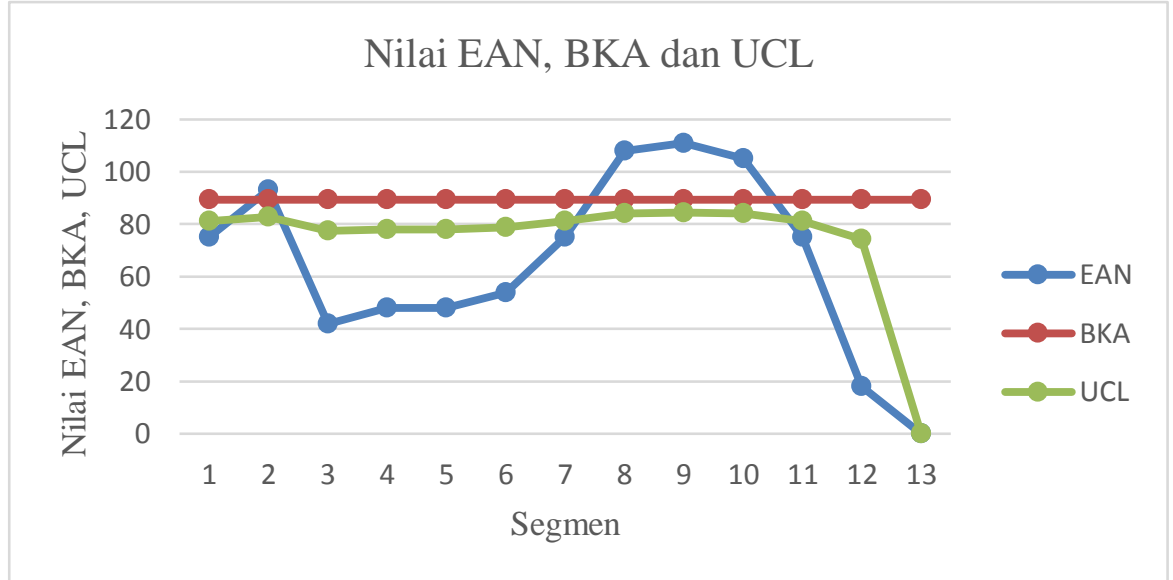

Gambar 5. Nilai EAN, BKA dan UCL

Pada tabel 5 dan gambar 5 menunjukan bahwa berdasarkan EAN, BKA dan UCL terlihat beberapa segmen yang berada diatas BKA dan UCL yaitu segmen 2 (KM. 13+000-KM. 14+000), segmen 8 (KM. 19+000-KM. 20+000), segmen 9 (KM. 20+000KM. 21+000) dan segmen 10 (KM. 21+000-KM. 22+000). Artinya bahwa di segmen 2, 8, 9 dan 10 masuk daerah rawan kecelakaan (blacksite). Berdasarkan hasil pengamatan dan data dilapangan terdapat beberapa titik blackspot. Daftar letak 4 titik blackspot ada pada tabel 6. 
Tabel 6. Titik Blackspot

\begin{tabular}{|c|c|c|c|c|c|}
\hline \multirow{2}{*}{ Segmen } & Ruas Jalan & $\begin{array}{c}\text { Nilai } \\
\text { EAN }\end{array}$ & $\begin{array}{c}\text { Nilai } \\
\text { BKA }\end{array}$ & $\begin{array}{c}\text { Nilai } \\
\text { UCL }\end{array}$ & Blackspot \\
\hline 2 & KM 13+000- KM 14+000 & 93 & 89,35 & 82,85 & KM 13+150 \\
\hline 8 & KM 19+000- KM 20+000 & 108 & 89,35 & 84,15 & KM 19+050 \\
\hline 9 & KM 20+000- KM 21+000 & 111 & 89,35 & 84,46 & KM 20+200 \\
\hline 10 & KM 21+000- KM 22+000 & 105 & 89,35 & 84 & KM 21+150 \\
\hline
\end{tabular}

\section{PENUTUP}

\section{Kesimpulan}

Jumlah kecelakaan yang paling tinggi pada tahun 2020 sebanyak 95 kejadian. Sedangkan jumlah kejadian kecelakaan tertinggi terjadi pada segmen 9 (KM. 20+000-KM. 21+000) dengan jumlah total 25 kejadian kecelakaan. Jenis korban kecelakaan yang paling tinggi pada tahun 2108 dengan total 92 korban dan terjadi penurunan setiap tahun, terendah 2020 dengan jumlah 54 korban. Berdasarkan nilai EAN terlihat beberapa segmen berada diatas BKA dan UCL yaitu segmen 2 (KM. 13+000-KM. 14+000), segmen 8 (KM. 19+000-KM. 20+000), segmen 9 (KM. 20+000KM. 21+000) dan segmen 10 (KM. 21+000-KM. 22+000). Artinya bahwa di segmen 2, 8, 9 dan 10 masuk daerah rawan kecelakaan (blacksite). Lokasi titik kecelakaan (blackspot) terdapat pada lokasi berikut:

1. KM. 13+000 - KM. 14+000 yang titik blackspot nya di KM. $13+150$

2. KM. 19+000 - KM. 20+000 yang titik blackspot nya di KM. $19+050$

3. KM. 20+000 - KM. 21+000 yang titik blackspot nya di KM. 20+200

4. KM. $21+000-$ KM. 22+000 yang titik blackspot nya di KM. 21+150

Faktor terbanyak penyebab kecelakaan adalah dari pengemudi terutama karena lengah atau kurang hati-hati sehingga tindakan yang dapat dilakukan untuk mengurangi kecelakaan terutama akibat pengemudi adalah pengendara harus selalu waspada, jangan lengah, apabila merasa lelah atau mengantuk segera beristirahat serta tidak lupa mengecek kondisi kendaraan yang akan digunakan terutama rem

\section{Saran.}

Peneliti selanjutnya diharapkan untuk mengkaji lebih lanjut termasuk mengamati kondisi geometrik dan perkerasan jalan agar hasil penelitian dalam menganalisa daerah rawan kecelakaan dapat lebih baik dan lebih lengkap lagi.

\section{Ucapan Terima Kasih}

Selesainya penelitian ini tidak terlepas dari bantuan berbagai pihak yang telah memberikan bantuan sehingga dapat disusun menjadi artikel yang lengkap.

\section{DAFTAR PUSTAKA}

Anonim, 2009. Undang-Undang No.22 tahun 2009, Tentang Lalu Lintas dan Angkutan Jalan.Pemerintah Republik Indonesia, Jakarta.

Agus Alisa Putra, Arfi Desrimon, 2019, Analisis Daerah Rawan Kecelakaan Lalu Lintas, Jurnal Teknik Industri Terintegrasi (JUTIN), Program Studi Teknik Sipil, Universitas Pahlawan Tuanku Tambusai. 
Asep Fahza, Hera Widyastuti, 2019, Analisis Daerah Rawan Kecelakaan Lalu Lintas Pada Ruas Jalan Tol Surabaya-Gempol. Jurnal Teknik ITS Vol 8 No 1, Institut Teknologi Sepuluh Nopember.

Bela Titisari, 2019. Analisis Kecelakaan Lalu Lintas (Studi Kasus: Kecelakaan Lalu Lintas Jalan Jogja-Solo Km. 17+300-Km. 49+800 Kabupaten Klaten), Program Studi T. Sipil, Univeritas Muhammadiyah Surakarta.

Bina Sistem Lalu Lintas dan Angkutan Kota, 1998. Pencegahan dan Penanganan Kecelakaan, Pusdiklat Perhubungan Darat,

Departemen Permukiman Dan Prasarana Wilayah. 2004. Pedoman Penanganan Lokasi Rawan Kecelakaan lalu Lintas (Pd T-09-2004-B). Jakarta.

Direktorat Keselamatan Transportasi Darat, 2007, Unit Penelitian Kecelakaan Lalu Lintas, Direktorat Jendral Perhubungan Darat, Jakarta

Djoko, P., Amelia, K. I., \& Kami, H. B. 2015. Hubungan antara Kecepatan dan Kondisi Geometrik Jalan yang Berpotensi Menyebabkan Kecelakaan Laalu Lintas pada Tikungan. Jurnal Ilmu Terapan Bidang Teknik Sipil, Vol. 21, No. 2,83-90.

Dwi Esti Intari, Hendrian Budi Bagus Kuncoro, Riana Pangestika, 2019, A Nalisis Kecelakaan Lalu Lintas Dan Biaya Kecelakan Materil Pada Ruas Jalan Nasional (Study Kasus: Jl. Raya Serang Km 23 Balaraja - Jl. Raya Serang Km 35 Jayanti Kabupaten Tangerang), Jurnal Fondasi Vol 8(1). Unoversitas Sultan Agung Tirtayasa.

Gito Sugiyanto, Ari Fadli. Identifikasi Lokasi Rawan Kecelakaan Lalu Lintas Dengan Metode Batas Kontrol Atas Dan Upper Control Limit, Program Studi Teknik Sipil, Fakultas TeknikUniversitas Jenderal Soedirman Purwokerto

Hobbs, F.D. 1995. Perencanaan Dan Teknik Lalu Lintas (Terjemahan). Yogyakarta: Universitas Gajah Mada.

Imam Samsudin, 2019, Analisa Faktor Penyebab Kecelakaan Pada Ruas Jalan Ir. H. Alala Kota Kendari Ditinjau dari Prasarana dan Geometrik Jalan, Puslitbang Transportasi Jalan dan Perkeretaapian.

Intan Kristalia Feryanti, 2019, Analisis Kecelakaan Lalu Lintas di Kota Surakarta, Progdi T. Sipil, Universitas Muhammadiyah Surakarta.

C. Jotin Khisty \& B. Kent Lall. 2003. Dasar-dasar Rekayasa Transportasi Jilid I Edisi Ketiga. Erlangga, Jakarta.

Nugroho Utomo, 2019, Analisa Faktor Penyebab Kecelakaan Lalu Lintas Pada Segmen Jalan By-Pass Krian-Balongbendo (KM. 26+000 - KM. 44+520), ejournal.upnjatim.ac.id. UPN Veteran Jatim. Diakses 6 November 2021.

Muhammad Fakhruriza Pradana, Dwi Esti Intari, Danur Pratidina, 2019, Analisa Kecelakaan Lalu Lintas dan Faktor Penyebabnya di jalan Raya Cilegon, Jurnal Kajian Teknik Sipil Vol 2 No 2 Tahun 2019, Universitas 17 Agustus 1945, Jakarta

Puslitbang, 2004, Penanganan Lokasi Rawan Kecelakaan Lalu Lintas, Pusat Penelitian dan Pengembangan Jalan, Balitbang PU, Bandung

Warpani, S.P., 2002, Pengelolaan Lalu Lintas dan Angkutan Jalan, Penerbit ITB, Bandung 